\title{
THE MEANING OF GOJEK ADVERTISING IN THE PANDEMIC ERA USING CHARLESS SANDER PIERCE SEMIOTICS ANALYSIS
}

\author{
Afny Rachma Safitri' ${ }^{1}$, Alvina Tara Afifa ${ }^{2}$, Achmad Chusaini Nasichul Amin ${ }^{3}$, Nur \\ Romdlon Maslahul Adi ${ }^{4}$ \\ ${ }^{1234}$ Sunan Ampel State Islamic University, Surabaya \\ 1afnyrachma@gmail.com, 2alvinatara24@gmail.com, 3sikul.acchu@gmail.com, \\ ${ }^{4}$ nur.romdlon.maslahul.adi@uinsby.ac.id
}

\begin{abstract}
The business competition faced by companies today is getting tighter, so it requires company management to be attentive in determining its competitive strategy. Advertising is tot only to promote a product, but also included a lot of social messages in it. Advertisements often use symbols or signs in describing their products. The messages in advertisements are in the form of text and visuals. This study aims to analyze the Sign, Object, Interpretant as well as the message and meaning in the Gojek advertisement version of "Pesan dari Rumah Buat Kita yang di Jalan". The research method uses a descriptive qualitative approach; this study uses the semiotic analysis method of the Charles Sander Pierce model. The results of the study show that the Gojek advertisement version of "Pesan dari Rumah Buat Kita yang di Jalan" invites the public to become people who continue to comply with health and savety protocols during the Covid-19 Pandemic. This advertisement is also a branding for Gojek as a safe community travel partner and always adheres to the health protocol recommendations during the Covid-19 pandemic.
\end{abstract}

Keywords: Advertising, Semiotics Analysis, Charles Sanders Pierce

\begin{abstract}
Abstrak: Persaingan bisnis yang dihadapi perusahaan saat ini semakin ketat, sehingga menuntut manajemen perusahaan untuk cermat dalam menentukan strategi bersaingnya. Iklan tidak hanya untuk mempromosikan suatu produk, tetapi juga memuat banyak pesan sosial di dalamnya. Iklan sering menggunakan simbol atau tanda dalam menggambarkan produknya. Pesan dalam iklan berupa teks dan visual. Penelitian ini bertujuan untuk menganalisis Sign, Object, Interpretant serta pesan dan makna dalam iklan Gojek versi "Pesan dari Rumah Buat Kita yang di Jalan". Metode penelitian menggunakan pendekatan kualitatif deskriptif; penelitian ini menggunakan metode analisis semiotika model Charles Sander Pierce. Hasil penelitian menunjukkan bahwa iklan Gojek versi "Pesan dari Rumah Buat Kita yang di Jalan" mengajak masyarakat untuk menjadi masyarakat yang tetap mematuhi protokol kesehatan dan keselamatan di masa Pandemi Covid-19. Iklan ini juga menjadi branding bagi Gojek sebagai partner travel komunitas yang aman dan selalu mematuhi anjuran protokol kesehatan di masa pandemi Covid-19.
\end{abstract}

Kata kunci: Iklan, Analisis Semiotika, Charles Sanders Pierce

\section{A. Introduction}

Business competition faced by companies today is getting tougher. This competition requires company management to be more careful in determining strategies to win the competition. Company management is required to projecting and employing marketing strategies to create, maintain, and increase customer satisfaction. One of the strategies taken is to continue to promote or advertise on various platforms. 
Advertising is defined as a form of communication in which the author or his sponsor sends messages to consumers with the aim of selling a product or idea. The renowned linguist Guy Cook defines advertising as 'parasite discourse', because it takes over the content, form, author and recipient of other discourses. ${ }^{1}$

Different types of ads have different characters. In making advertisements, creative ideas and concepts are needed. The persuasive message received by the community depends on the creativity of an idea. ${ }^{2}$ Advertising is part of a form of communication that is visualized through various concepts of signs or meanings. ${ }^{3}$ The meaning of the signs can be seen and determined by using a pattern of interpretation of the sign. Sign is something that is physically perceived by our minds and refers to something other than the sign and depending on the opinion of the use itself that it is a sign.

Advertising as a manifestation of mass culture aims to offer and influence potential consumers to buy goods or services and create certain values. ${ }^{4}$ The purpose of advertising is to persuade, acquire, evaluate, influence. In other words advertising is to shape the awareness of the recipients, to reinforce their need to buy a certain product or service. As a type of persuasion, advertising is influenced by verbal, non-verbal, word-forming, syntactic and lexical factors, whose effects are individual and varied. ${ }^{5}$

To influence and deliver social messages is what transportation startup Gojek takes. Gojek has always consistently exposed to advertising by creating new innovations to maintain customer loyalty. Gojek always makes advertisements with different versions at every moment or occasion, one of which is a quite interesting advertisement, the version of "Pesan dari Rumah Buat Kita yang di Jalan".

The Gojek ad version of "Pesan dari Rumah Buat Kita yang di Jalan" was presented along with the ongoing Covid-19 pandemic. Gojek's version of the "Order from Home for those of us on the Road" version, Gojek explained that there have been various kinds of activities in life since the COVID-19 pandemic that requires us to always maintain health. Not just an advertisement, the Gojek ad version of "Pesan dari Rumah Buat Kita yang di Jalan" invites the public to comply with health protocols to avoid Covid-19 and the pandemic will end quickly. This advertisement is also a step that Gojek cares about the health of driver and customer partners. Gojek advertisements which not only contain promotional elements but also elements of social movement invitations make this advertisement need to be analyzed further.

Advertisements that also highlight the social situation during the COVID-19 period have also been analyzed in China. China Covid Public Service Advertisement was built positively to build people's confidence in fighting the virus, educate people to be grateful and united, to shape China's good image globally. China Covid-PSA is a way of communication to deal with public health ills, influence theory is used to manipulate public emotions, facial theory is to maintain a positive image to the public, cooperation theory is to answer what the audience needs such as emotional support and confidence. ${ }^{6}$ Therefore, broadcasters report more content on social values

\footnotetext{
${ }^{1}$ Martin Solík, "Semiotic Approach to Analysis of Advertising," European Journal of Science and Theology 10, no. 1 (2014): 207-217.

${ }^{2}$ Cheryandina Mutya Kinasih and Arie Prasetio, "Makna Cantik Pada Iklan The Body Shop Indonesia Versi 'CANTIK ITU... | \#MYTRUTH \#SKINTRUTH' Di Youtube (Analisis Semiotika Charles Sanders Peirce)," in EProceedings of Management, vol. 7, 2020, 7123-7132.

3 Dudi Hartono and Asep Sugalih, "Makna Simbol Senyum Pada Iklan Lay'S Di Televisi (Semiotics Analyisis of Charles Sanders Pierce)," Jurnal Perspektif Komunikasi 3, no. 1 (2019): 41-46.

${ }^{4}$ Dona Rahayu Sugiharti, "Beauty Construction on Pond's White Beauty Gita Gutawa Version: Semiotic Analysis of Advertisement," in International Conference on Language Phenomena in Multimodal Communication (KLUA 2018), vol. 228, 2018, 384-388.

5 Solík, "Semiotic Approach to Analysis of Advertising."

6 Ruinan Zhao, "A Social Semiotic Analysis of Covid-19 Public Service Advertisements in China," in Proceedings of the 2nd International Conference on Language, Art and Cultural Exchange (ICLACE 2021), vol. 559, 2021, 256-259.
} 
than protective guidance or instruction. This paper analyzes semiotics in Gojek advertisements. Furthermore, this study discusses the semiotic analysis of Charles Sanders Peirce.

\section{B. Theoretical Review}

An American philosopher Charles Sanders Peirce, one of the most popular in the theory of sign said that signs had substituted something for someone.7 Semiotics by Peirce is defined as the study of signs and everything related to them; how to function (syntactic semiotic), the relationship among signs (semantic semantics), and examines the sender and receiver by those who use the signs (semiotic pragmatics). Peirce states that the process of significance is necessary since humans contribute meaning to the reality they meet. According to Peirce, this implies that language is closely related to reality, and for him, signs start from human cognition dynamically. ${ }^{8}$

Peirce views the subject as an inseparable part of process of meaning. Peirce's triadic model $($ representamen + object + interpretant $=$ sign $) .{ }^{9}$ Peirce's triadic model shows three main elements forming a sign, namely representamen, object, and interpretant. ${ }^{10}$ Symbols, meanings, and representations are important in the formation of meaning. Every aspect related to the formation of symbols reflects a problem that is so complex to interpret.11

The semiotic analysis of advertising assumes that the meanings are designed by their creators to shape and lend significance to our reality. We are encouraged to see ourselves, the products and the services advertised and aspects of our social world in terms of the mythic meanings that the advertisements promote. ${ }^{12}$

In analyzing advertising semiotics, we must separate the ad from its environment. We need to identify visual and linguistic signs in advertising, to see how the signs are structured paradigmatically and to pay attention to how the signs relate to each other through various coding systems. We need to identify which social myths are lifted from the ad and which myths are reinforced. We also need to realize that all codes are potentially ambiguous and that different readers have the potential to decode tokens differently. We can assume that anything that brings meaning to us in an advertisement is a sign. So, linguistic signs and iconic signs all act as signs that add to the code and cumulative meaning. ${ }^{13}$

With the development of technology or science, advertising is no longer rigid and monotonous. Advertising is also closely related to culture or lifestyle. Because an advertisement can introduce a culture that sometimes the audience is not even aware of. ${ }^{14}$ Advertising as a

\footnotetext{
${ }^{7}$ Farhan Muhammad Ramadhan, Shavira Nisa Delardhi, and Ula Nisa El Fauziah, "Sign Analysis of the Instagram User Using Semiotic Charles S. Peirce," PROJECT (Professional Journal of English Education) 1, no. 5 (2018): 631-644.

${ }^{8}$ Hanifa Sa'diyah, I Wayan Suardana, and Rapi Renda, "The Philosophical Meanings of Tapis Limar Sekebar and Bintang Perak: A Semiotic Perspective of Charles Sanders Peirce," in Proceedings of the 4th International Conference on Arts and Arts Education (ICAAE 2020), vol. 552, 2021, 277-282.

9 Diany Asritisthia, Kusnadi, and MeliarikaWidyanti Putri, "Semiotics Study on the Oncer Dance Performance Art: A Charles Sanders Peirce's Perspective," in Proceedings of the 4th International Conference on Arts and Arts Education (ICAAE 2020), vol. 552, 2021, 273-276.

10 Erna Kurniawati, "Video Musik Sabyan Gambus 'Atouna El Toufoule' Studi Analisis Semiotika Charles Sanders Peirce," Al-Munzir 12, no. 1 (2019): 97-121.

11 Michael Jibrael Rorong, “Representasi Nilai Kemanusiaan Web Series Kisah Carlo," Jurnal Semiotika 13, no. 1 (2019): 106-123.

12 Alok Kumar Jha, Amrita Raj, and Rachana Gangwar, "A Semiotic Analysis of Portraying Gender in Magazine Advertisements," IOSR Journal Of Humanities And Social Science (IOSR-JHSS) 22, no. 5 (2017): 18, www.iosrjournals.org.

13 Ibid.

14 Rizky Ridha Ananda and Twin Agus Pramonojati, "Pornografi Pada Iklan Televisi Shopee (Analisis Semiotika Charles Sanders Peirce Pada Iklan Shopee Versi Blackpink)," in EProceedings of Management, vol. $6,2019,5254-5259$.
} 
semiotic object, has a direct communication function. Therefore, in advertising, communication aspects such as messages are the main elements of advertising. 15

Semiotics is the study of symbols or signs and the study of meaning which is a wide variety of activities and processes involving signs. In principle, semiotics studies how humans interpret things that are around them. Images, signs, symbols, and everything that surrounds us, both verbal and non-verbal, are used to represent something or convey messages to the intended audience. Most of the signs in advertisements are used to represent an object and persuade people to pay attention and read the advertisement. ${ }^{16}$

\section{Methods}

The research method used is a qualitative research method because the object under study is closely related to communication. Qualitative research is research that is used to find out and analyze what is not visible. In other words, qualitative methods aim to see the contents of implied communication. ${ }^{17}$

This study aims to see the signs, messages, and meanings contained in the Gojek television advertisement version of "Pesan dari Rumah Buat Kita yang di Jalan". The method used in this study is semiotic analysis, in this study completely based on general thinking, namely the semiotic analysis of Charles Sanders Pierce's model which is used only as the basis and normative of this research.

The semiotic analysis of Charles Sander Pierce was chosen because the researcher examined more deeply about the signs in Gojek's advertisements. Peirce introduced a semiotic triangle meaning to define signs including representation, object and interpreter. ${ }^{18}(1)$ the sign in the narrow sense, also referred to as the re-presentment, that which represents something else; (2) the object, that which the sign stands for, that which is represented by it; a finally (3) the (possible or potential) meaning the sign allows for, which may materialize as its translation into a new sign. Peirce refers to this as the interpretant. ${ }^{19}$

The data processing technique was done by four stages: a) seeing the adv of Gojek, b) observing every scene, starting from the background, expressions, and the narrative used. c) doing screen capture on every shooting scene/scene, d) analyzing the data with Charles Sanders Peirce's analysis. The process of analyzing data in this process is by examining all data obtained from various sources. Next, the data are reduced, interpreted, and processed through concluding using the Charles Sanders Peirce model of semiotics analysis. ${ }^{20}$

\section{Results and Discussion}

From the description of the previous theory and concept, this research was studied using the semiotic analysis method of Charles Sanders Pierce. This study analyzes the aspect of taking pictures, voice acting, background, expressions, verbal and non-verbal messages.

\footnotetext{
${ }^{15}$ Hartono and Sugalih, "Makna Simbol Senyum Pada Iklan Lay'S Di Televisi (Semiotics Analyisis of Charles Sanders Pierce)."

${ }^{16}$ Ni Made Desi Trisnayanti, Desak Putu Eka Pratiwi, and Komang Dian Puspita Candra, "Discovering Hidden Messages in Covid-19 Advertisement 'Stay Home Save Lives': A Semiotic Analysis," RETORIKA: Jurnal Ilmu Bahasa 7, no. 1 (2021): 25-31.

${ }^{17}$ Abdul Malik, Raray Istianah, and Bachrul Restu Bagja, "Analisis Semiotika Charles Sanders Peirce Tentang Makna Logo Pariwisata Kabupaten Sukabumi," Jurnal Ilmu Komputer dan Desain Komunikasi Visual 6, no. 1 (2021): 40-49.

18 Ibid.

${ }^{19}$ Ramadhan, Delardhi, and Fauziah, "Sign Analysis of the Instagram User Using Semiotic Charles S. Peirce."

${ }^{20}$ Asna Istya Marwantika, "The Sacralization of the Myth of Prohibition of Leaving the House at Dusk in Sandekala Film: Charles Sanders Pierce's Semiotic Analysis," MUHARRIK: Jurnal Dakwah dan Sosial 4, no. 01 (2021): 33-46.
} 


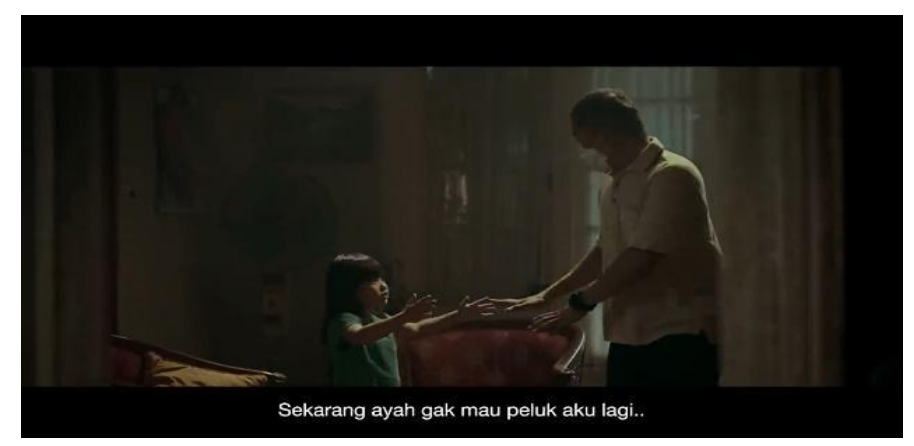

Figure 1 Scene 1 of Gojek Adv

Table 1 Analysis of Scene 1

\begin{tabular}{|c|c|c|}
\hline Representament & Object & Interpretant \\
\hline $\begin{array}{l}\text { 1. Shooting technique. Eye Level shooting angle } \\
\text { with image size Medium Shot. } \\
\text { 2. The black background or background is dim, } \\
\text { depicting the night. } \\
\text { 3. Verbal messages show a child who wants to } \\
\text { hug his father, but the father forbids him to } \\
\text { hug. The non-verbal message is that the } \\
\text { father does not want his son to approach the } \\
\text { father who has just come home from work. } \\
\text { 4. Advertisement text: "Sekarang ayah gak mau } \\
\text { peluk aku lagi". }\end{array}$ & $\begin{array}{l}\text { A child who wants } \\
\text { to hug his father by } \\
\text { extending his hand, } \\
\text { but is rejected by } \\
\text { his father with a } \\
\text { hand gesture of } \\
\text { distancing. }\end{array}$ & $\begin{array}{l}\text { In this advertisement, } \\
\text { the father, who just } \\
\text { came home from } \\
\text { work, keeps his son } \\
\text { away with the aim } \\
\text { that his son is not } \\
\text { exposed to viruses or } \\
\text { germs from outside } \\
\text { that stick to the } \\
\text { father's body. }\end{array}$ \\
\hline
\end{tabular}

In scene 1, the shooting technique is done with the Eye Level technique with a Medium Shot image size, because in this scene it shows 2 objects, namely the child and father by showing the size of the Long Shot image so that the child and father are seen in the frame, by hinting a father who refuses to be hugged by a child.

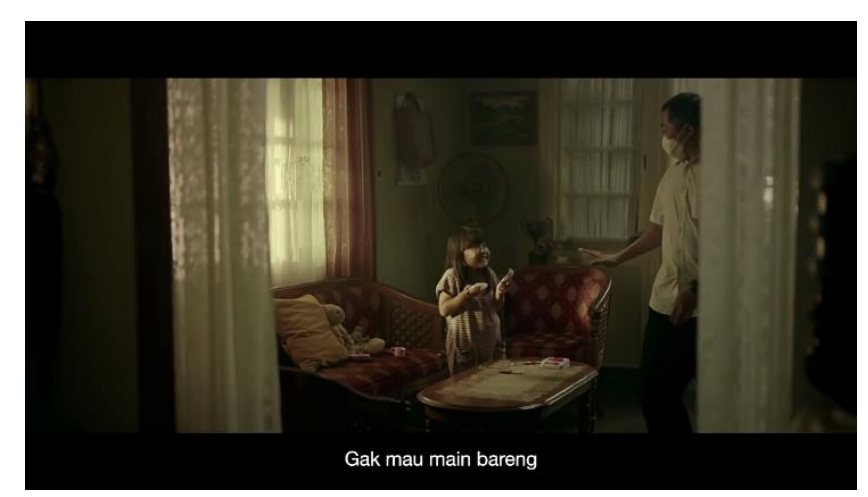

Figure 2 Scen 2 of Gojek Adv 
Table 2 Analysis of Scene 2

\begin{tabular}{|c|c|c|}
\hline Representament & Object & Interpretant \\
\hline $\begin{array}{l}\text { 1. Shooting technique: Eye Level shooting angle } \\
\text { with Long Shot image size. } \\
\text { 2. The background or background is dark, but } \\
\text { there is a reflection of light from outside } \\
\text { which indicates being at home in the } \\
\text { morning or afternoon. } \\
\text { 3. Verbal messages show a child who invites his } \\
\text { father to play with him, but is rejected by } \\
\text { the father. Non-verbal messages, where the } \\
\text { father does not want his son to approach } \\
\text { him who just got home from work. } \\
\text { 4. Advertisement text: "Gak mau main bareng". }\end{array}$ & $\begin{array}{l}\text { A child who offers a } \\
\text { fork and a glass lid } \\
\text { to invite his father } \\
\text { to play with him, } \\
\text { but his father } \\
\text { refuses with a } \\
\text { distant hand } \\
\text { gesture. }\end{array}$ & $\begin{array}{l}\text { This ad teaches to } \\
\text { keep a distance due } \\
\text { to a pandemic that it } \\
\text { is not known } \\
\text { whether there is a } \\
\text { virus attached to the } \\
\text { body or clothes worn, } \\
\text { to stop the spread of } \\
\text { covid-19. }\end{array}$ \\
\hline
\end{tabular}

In scene 2 uses the Eye Level shooting technique with a Long Shot image size or a full object with a background, which means highlighting the object against the background. Gives a clearer picture of the object. Shows the activity of the child playing cooking and inviting the father who just came home from work with a happy face, but suddenly sad because the father refuses the child's invitation to play together.

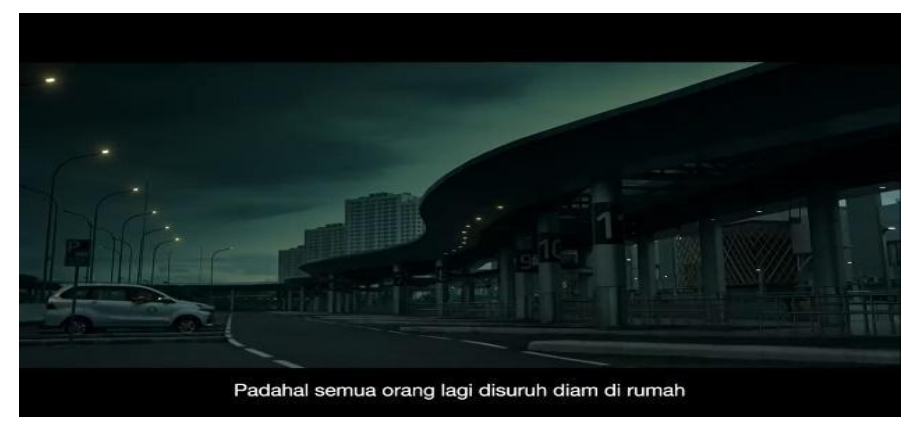

Figure 3 Scene 3 of Gojek Adv

Table 3 Analysis of Scene 3

\begin{tabular}{|c|c|c|}
\hline Representament & Object & Interpretant \\
\hline $\begin{array}{l}\text { 1. Shooting technique: Eye Level shooting angle } \\
\text { with Long Shot image size. } \\
\text { 2. Background or dark color background, with } \\
\text { the evening sky indicating that the time } \\
\text { setting is approaching evening. } \\
\text { 3. Verbal messages show that during the } \\
\text { pandemic, people are encouraged to work } \\
\text { from home. Non-verbal messages, the father } \\
\text { as the head of the family still has to provide } \\
\text { for the family by working, and his work } \\
\text { cannot be done from inside the house. } \\
\text { 4. Advertisement text: "Padahal semua orang } \\
\text { lagi disuruh diam di rumah". }\end{array}$ & $\begin{array}{l}\text { A working father } \\
\text { waits for } \\
\text { passengers from } \\
\text { inside the car. }\end{array}$ & $\begin{array}{l}\text { Shows that the father } \\
\text { is making a living for } \\
\text { his family despite } \\
\text { being in a pandemic } \\
\text { situation which } \\
\text { requires everyone to } \\
\text { follow the applicable } \\
\text { health protocols and } \\
\text { is encouraged to } \\
\text { carry out their } \\
\text { activities from home. }\end{array}$ \\
\hline
\end{tabular}

Scene 3 use the Eye Level shooting technique with a Long Shot image size or a full object with a background with the intention of showing the background of the place at that time, namely 
the sky which is already showing the evening time which means that the father is working from morning to night to make ends meet his family. While the atmosphere depicted in the scene seems quiet and there is only a car carrying the father, which implies that during a pandemic, people are encouraged to stay at home to avoid transmitting the virus. By limiting gatherings and avoiding crowds, maintaining cleanliness, and implementing health and safety protocols.

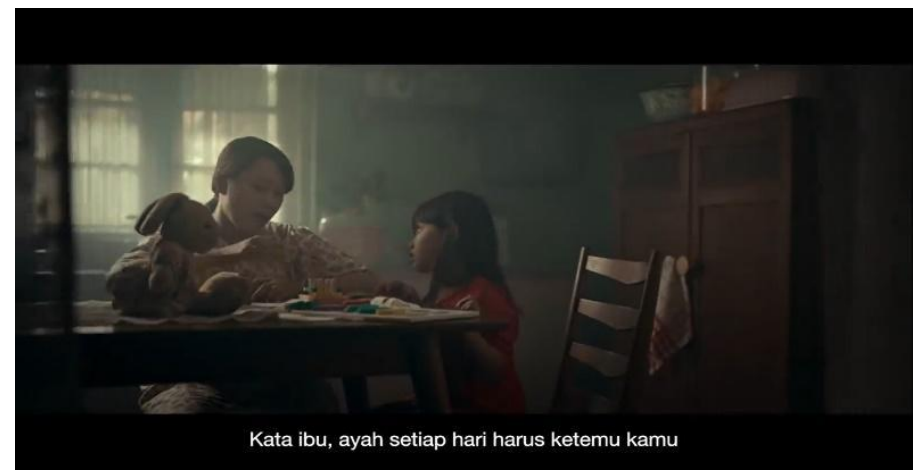

Figure 4 Scene 4 of Gojek Adv

Table 4 Analysis of Scene 4

\begin{tabular}{|c|c|c|}
\hline Representament & Object & Interpretant \\
\hline $\begin{array}{l}\text { 1. Shooting technique: Eye Level shooting angle } \\
\text { with Medium Shot image size. } \\
\text { 2. The background is dark because it is in the } \\
\text { room, but the window shows the time } \\
\text { background, namely in the morning because } \\
\text { there is sunlight that penetrates from between } \\
\text { the windows. } \\
\text { 3. Verbal messages indicate that the mother is } \\
\text { explaining to her child about the current } \\
\text { condition. About the demands of the father's } \\
\text { job which requires his father to work outside } \\
\text { even though he is in a state of the covid-19 } \\
\text { pandemic. Non-verbal messages, family } \\
\text { togetherness that can only be filled by mother } \\
\text { and child, while the father has to go out of the } \\
\text { house to earn a living. } \\
\text { 4. Advertisement text: "Kata Ibu, Ayah setiap hari } \\
\text { harus ketemu kamu". }\end{array}$ & $\begin{array}{l}\text { A mother, who } \\
\text { was teaching the } \\
\text { child, and told } \\
\text { him about the } \\
\text { current } \\
\text { condition of the } \\
\text { family. }\end{array}$ & $\begin{array}{l}\text { Indicates that the } \\
\text { mother is trying to } \\
\text { explain to her child } \\
\text { the current condition. } \\
\text { The reason the father } \\
\text { had to keep going out } \\
\text { of the house to work } \\
\text { to make a living for } \\
\text { the family. so that his } \\
\text { father rarely plays } \\
\text { with him, different } \\
\text { from the days before } \\
\text { the pandemic }\end{array}$ \\
\hline
\end{tabular}

Scene 4 plays Eye Level with Medium Shot image size for shooting techniques because in this scene it shows 2 objects, namely the child and mother by showing the Long Shot image size so that the child and mother are seen in the frame, with the mother talking to the child. Explaining the circumstances experienced by his family and current conditions caused the father to have to keep his distance after coming home from work. 


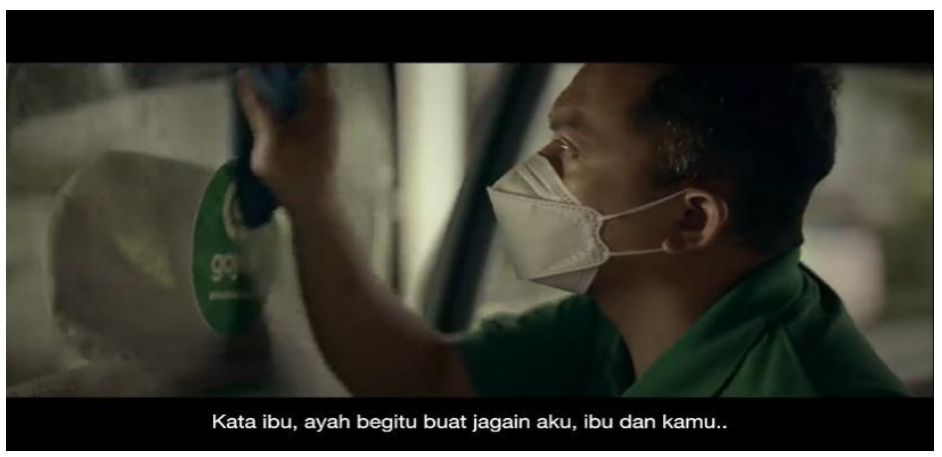

Figure 5 Scene 5 of Gojek Adv

Table 5 Analysis of Scene 5

\begin{tabular}{|c|c|c|}
\hline Representament & Object & Interpretant \\
\hline $\begin{array}{l}\text { 1. Shooting technique: Eye Level shooting angle } \\
\text { with Close Up image size. } \\
\text { 2. The background or the background of the } \\
\text { father being in the car, cleaning the car } \\
\text { barrier that separates the driver and } \\
\text { passengers. And the father also continues to } \\
\text { wear a mask when cleaning the barrier. By } \\
\text { displaying the Gojek logo on the barrier that } \\
\text { is being cleaned by my father, it shows that } \\
\text { this commercial ad was published by Gojek. } \\
\text { 3. Verbal messages indicate that the father is } \\
\text { clearing the transparent barrier to limit } \\
\text { himself, and the passengers. Which } \\
\text { indicates that the vehicle is kept clean. That } \\
\text { way, the driver (father), passengers, and } \\
\text { their families are protected from the risk of } \\
\text { contracting the COVID-19 virus. } \\
\text { Non-verbal messages, vehicles from Gojek } \\
\text { are always used clean, and kept clean. And } \\
\text { the driver from Gojek always keeps his } \\
\text { vehicle and himself clean. } \\
\text { 4. Ad text: "Kata ibu, ayah begitu buat jagain } \\
\text { aku, ibu dan kamu". }\end{array}$ & $\begin{array}{l}\text { A father who works } \\
\text { as an online } \\
\text { motorcycle taxi } \\
\text { driver from Gojek is } \\
\text { cleaning the vehicle } \\
\text { he uses for work. }\end{array}$ & $\begin{array}{l}\text { Shows that my father } \\
\text { works as an online } \\
\text { motorcycle taxi } \\
\text { driver from Gojek } \\
\text { always prioritizes the } \\
\text { cleanliness and safety } \\
\text { of his passengers and } \\
\text { loved ones by } \\
\text { continuing to wear } \\
\text { masks. The father } \\
\text { cleared the barrier } \\
\text { with the Gojek logo } \\
\text { that became a barrier } \\
\text { between the driver } \\
\text { and passengers. }\end{array}$ \\
\hline
\end{tabular}

The Eye Level technique with Close Up image size is used in scene 5. This scene shows the details of a father who cleans the vehicle he will use for work, precisely the barrier between the driver and passengers. The advertisement shows that Gojek always prioritizes the cleanliness and safety of passengers and their loved ones by still wearing masks, the father clearing the barrier with the Gojek logo which is the boundary between the driver and passengers. 


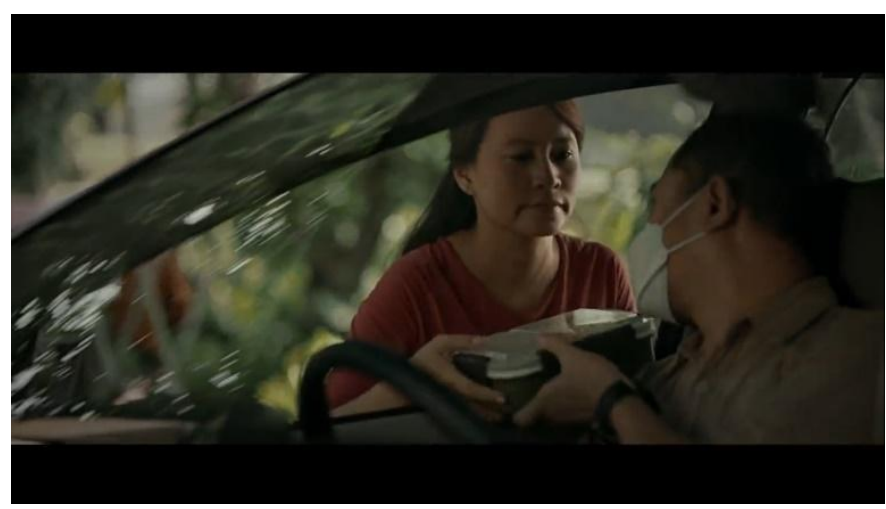

Figure 6 Scene 6 Gojek Adv

Table 6 Analysis of Scene 6

\begin{tabular}{|c|c|c|}
\hline Representament & Object & Interpretant \\
\hline $\begin{array}{l}\text { 1. Shooting technique: Eye Level shooting angle } \\
\text { with Medium Close Up image size. } \\
\text { 2. The background or the background of the } \\
\text { father being in the car, and there is a bright } \\
\text { light behind the mother, which indicates the } \\
\text { morning / father who wants to go to work. } \\
\text { 3. Verbal messages indicate that giving dad } \\
\text { breakfast to eat and remind him to change } \\
\text { masks frequently. Non-verbal message, } \\
\text { Mother reminded father to maintain } \\
\text { immunity by eating, and maintain health by } \\
\text { changing masks according to the feasibility of } \\
\text { wearing masks. } \\
\text { 4. Advertisement text: "Ibu selalu ingetin ayah". }\end{array}$ & $\begin{array}{l}\text { A father who is an } \\
\text { online motorcycle } \\
\text { taxi from Gojek is } \\
\text { cleaning the vehicle } \\
\text { he will use for work. }\end{array}$ & $\begin{array}{l}\text { Shows that the } \\
\text { mother, the wife of } \\
\text { a Gojek driver, also } \\
\text { reminded her to } \\
\text { maintain health by } \\
\text { reminding her to } \\
\text { change her father's } \\
\text { mask regularly. }\end{array}$ \\
\hline
\end{tabular}

In scene 6, the shooting technique is done using the Eye Level technique with a Medium Close Up image size, because in this scene it shows 2 objects, namely father and mother who are giving food that is left behind. The mother seems to remind how important it is to change masks frequently.

Table 7 Analysis of Scene 7

\begin{tabular}{|ll|l|l|}
\hline \multicolumn{1}{|c|}{ Representament } & \multicolumn{1}{c|}{ Object } & \multicolumn{1}{c|}{ Interpretant } \\
\hline 1. $\begin{array}{l}\text { Shooting technique: Eye Level shooting angle } \\
\text { with Big Close Up image size. }\end{array}$ & $\begin{array}{l}\text { The customer } \\
\text { uses a mask and } \\
\text { puts on the mask } \\
\text { according to the } \\
\text { 2. } \begin{array}{l}\text { The background or the background of the } \\
\text { father being in the car and the direction of } \\
\text { view is heading out the window. }\end{array}\end{array}$ & $\begin{array}{l}\text { Shows that Gojek } \\
\text { prioritizes health } \\
\text { by providing } \\
\text { education to } \\
\text { continue to use } \\
\text { masks properly. }\end{array}$ \\
$\begin{array}{l}\text { Verbal messages indicate that the voice over } \\
\text { warned not to lower the mask. Non-Verbal } \\
\text { Message, this advertisement reminds } \\
\text { customers to use masks according to } \\
\text { government recommendations, and not to } \\
\text { lower masks, with the aim that germs / } \\
\text { viruses cannot enter through the sense of } \\
\text { smell. }\end{array}$ & \\
\hline
\end{tabular}


4. Advertisement text: "Kamu juga yah, maskernya jangan sampai turun".

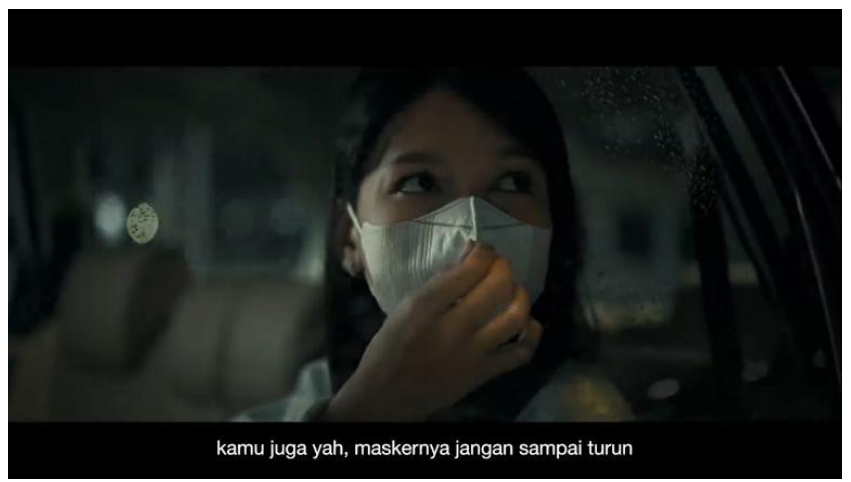

Figure 7 Scene 7 of Gojek Adv

Scene 7 uses the Eye Level shooting technique with a Big Close Up image size, because this scene shows the detail of the customer object that shows the correct use of the mask, by raising the mask according to the recommendation.

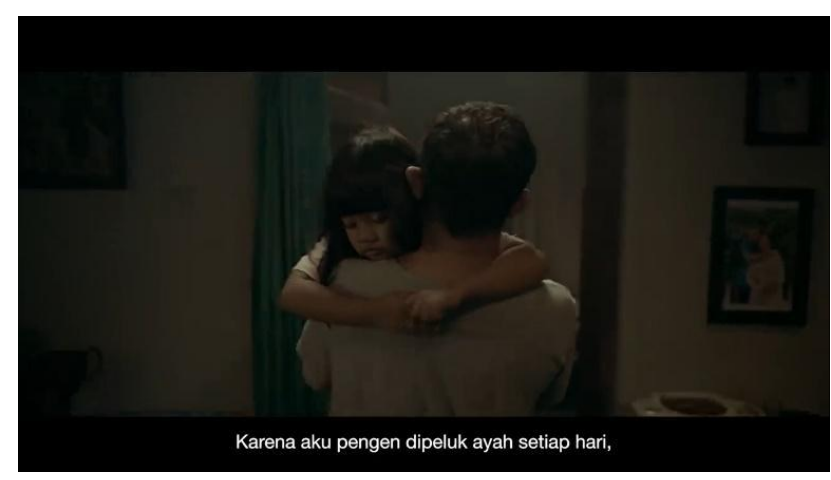

Figure 8 Scene 8 of Gojek Adv

Table 8 Analysis of Scene 8

\begin{tabular}{|c|c|c|}
\hline Representament & Object & Interpretant \\
\hline $\begin{array}{l}\text { 1. Shooting technique: Eye Level shooting angle } \\
\text { with Medium Shot image size. } \\
\text { 2. The background or the background of the } \\
\text { father being in the house, with the lighting in } \\
\text { the video dark, shows a sadness. } \\
\text { 3. Verbal messages indicate that child that the } \\
\text { father wants to hug every day. Non-Verbal } \\
\text { Messages, message to maintain health for you } \\
\text { (customers) and father. So that the father } \\
\text { stays healthy and can hug the child every day. } \\
\text { 4. Ad text: "Karena aku pengen dipeluk ayah } \\
\text { setiap hari, walaupun Cuma sebentar". }\end{array}$ & $\begin{array}{l}\text { A father who } \\
\text { finished cleaning } \\
\text { himself from work, } \\
\text { picked up his } \\
\text { sleeping child in a } \\
\text { chair and moved } \\
\text { him on the bed. }\end{array}$ & $\begin{array}{l}\text { Shows that before the } \\
\text { father holds the child, } \\
\text { he cleans his body first } \\
\text { after work so as not to } \\
\text { transmit the virus that } \\
\text { is in the clothes that } \\
\text { the father wears after } \\
\text { working all day. }\end{array}$ \\
\hline
\end{tabular}

Eye Level with Medium Shot image size in Scene 8 is used because in this scene it shows 2 objects. Where in the ad the father after cleaning himself from work. The father hugged the child and moved him on the bed. 


\section{Verbal and Non-Verbal Messages Analysis}

From the overall analysis of the message in the Gojek advertisement version of "Pesan dari Rumah Buat Kita yang di Jalan" these are the words that come out of a child who is inframe as well as voice over. The non-verbal message contained in this advertisement is to try to still being able to facilitate people to work in pandemic, besides that Gojek is an application that always obeys government rules by maintaining health protocols, especially during the pandemic season. The way to maintain health is by giving directions to partners and customers to comply with health protocols such as masks, besides that partners also provide good service by providing customer and driver barriers to avoid the virus. Gojek invites the public to continue their activities despite the pandemic, while maintaining health protocols.

\section{Advertisement Meaning}

From the results of the analysis of signs and messages that have been done scene by scene, this Gojek advertisement has the meaning of complying with health protocols in activities where each scene describes an activity to maintain health protocols.

People are required to keep their distance and maintain cleanliness, by doing 5M: 1) Wearing a mask; 2) Wash your hands with soap and running water; 3) Keep your distance; 4) Stay away from the crowd; and 5) Limiting mobilization and interaction

Gojek advertisement "Pesan Dari Rumah Untuk Yang Dijalan" presents the implementation of health protocols during pandemic. The advertisement shows there is a message from people at home to maintain health out there to keep the family at home safe because during this pandemic, the virus can be spreading everywhere.

So, the overall meaning conveyed in the Gojek ad "Message from home for us on the road" is a solution to reduce the number of viruses spread during this pandemic. Adhering to health protocols is a step to change things for the better. The word message from home for those of us who are on the road is a word that can bring up a sense of self-awareness to maintain health protocols because there are families at home waiting.

In this advertisement there are also 3 messages, first, for yourself (the father), the second for the customer, and the third for the family at home. The first message is a message to change masks, the second message describes to keep each other at a distance in activities. And the last message describes to always clean up before gathering with family.

The message conveyed in this advertisement is Gojek's effort to do a persuasive way to lead customers to use Gojek's services to make traveling easier, with the various services it has because Gojek pays attention to health protocols.

\section{E. Conclusion}

In this study, the sign, object and interpretant are seen from shooting techniques, colors, sound and text. This advertisement provides education to comply with health protocols for the safety of everyone. In this study the messages are given in the form of verbal and nonverbal messages. All verbal messages that have been analyzed that is the voice of a child are words that come out of a child which is inframe as well as being voice over. The non-verbal message contained in this advertisement is that Gojek try to be a place for people to work, besides being an application that always obeys government rules by always maintaining health protocols in this pandemic season.

Gojek's commercial advertisement advice version of "Pesan dari Rumah Buat yang di Jalan" presents signs, messages and meanings related to semiotics in advertisements is being creative by making advertisements so that the meaning and message can be conveyed properly to the public. 


\section{References}

Ananda, Rizky Ridha, and Twin Agus Pramonojati. "Pornografi Pada Iklan Televisi Shopee (Analisis Semiotika Charles Sanders Peirce Pada Iklan Shopee Versi Blackpink)." In EProceedings of Management, 6:5254-5259, 2019.

Asritisthia, Diany, Kusnadi, and MeliarikaWidyanti Putri. "Semiotics Study on the Oncer Dance Performance Art: A Charles Sanders Peirce's Perspective." In Proceedings of the 4th International Conference on Arts and Arts Education (ICAAE 2020), 552:273-276, 2021.

Hartono, Dudi, and Asep Sugalih. "Makna Simbol Senyum Pada Iklan Lay' S Di Televisi (Semiotics Analyisis of Charles Sanders Pierce)." Jurnal Perspektif Komunikasi 3, no. 1 (2019): 41-46.

Jha, Alok Kumar, Amrita Raj, and Rachana Gangwar. "A Semiotic Analysis of Portraying Gender in Magazine Advertisements." IOSR Journal Of Humanities And Social Science (IOSR-JHSS) 22, no. 5 (2017): 18. www.iosrjournals.org.

Kinasih, Cheryandina Mutya, and Arie Prasetio. "Makna Cantik Pada Iklan The Body Shop Indonesia Versi 'CANTIK ITU... | \#MYTRUTH \#SKINTRUTH' Di Youtube (Analisis Semiotika Charles Sanders Peirce).” In EProceedings of Management, 7:7123-7132, 2020.

Kurniawati, Erna. "Video Musik Sabyan Gambus 'Atouna El Toufoule' Studi Analisis Semiotika Charles Sanders Peirce." Al-Munzir 12, no. 1 (2019): 97-121.

Malik, Abdul, Raray Istianah, and Bachrul Restu Bagja. "Analisis Semiotika Charles Sanders Peirce Tentang Makna Logo Pariwisata Kabupaten Sukabumi." Jurnal Ilmu Komputer dan Desain Komunikasi Visual 6, no. 1 (2021): 40-49.

Marwantika, Asna Istya. "The Sacralization of the Myth of Prohibition of Leaving the House at Dusk in Sandekala Film: Charles Sanders Pierce's Semiotic Analysis." MUHARRIK: Jurnal Dakwah dan Sosial 4, no. 01 (2021): 33-46.

Ramadhan, Farhan Muhammad, Shavira Nisa Delardhi, and Ula Nisa El Fauziah. "Sign Analysis of the Instagram User Using Semiotic Charles S. Peirce." PROJECT (Professional Journal of English Education) 1, no. 5 (2018): 631-644.

Rorong, Michael Jibrael. "Representasi Nilai Kemanusiaan Web Series Kisah Carlo." Jurnal Semiotika 13, no. 1 (2019): 106-123.

Sa'diyah, Hanifa, I Wayan Suardana, and Rapi Renda. "The Philosophical Meanings of Tapis Limar Sekebar and Bintang Perak: A Semiotic Perspective of Charles Sanders Peirce." In Proceedings of the 4th International Conference on Arts and Arts Education (ICAAE 2020), 552:277-282, 2021.

Solík, Martin. "Semiotic Approach to Analysis of Advertising." European Journal of Science and Theology 10, no. 1 (2014): 207-217.

Sugiharti, Dona Rahayu. "Beauty Construction on Pond's White Beauty Gita Gutawa Version: Semiotic Analysis of Advertisement." In International Conference on Language Phenomena in Multimodal Communication (KLUA 2018), 228:384-388, 2018.

Trisnayanti, Ni Made Desi, Desak Putu Eka Pratiwi, and Komang Dian Puspita Candra. "Discovering Hidden Messages in Covid-19 Advertisement 'Stay Home Save Lives': A Semiotic Analysis." RETORIKA: Jurnal Ilmu Bahasa 7, no. 1 (2021): 25-31.

Zhao, Ruinan. "A Social Semiotic Analysis of Covid-19 Public Service Advertisements in China." In Proceedings of the 2nd International Conference on Language, Art and Cultural Exchange (ICLACE 2021), 559:256-259, 2021. 